\title{
MR-Augmented Cardiopulmonary Exercise Testing- a proof of concept in Sickle Cell Disease (SCD)
}

\author{
Emmanuel O Ako ${ }^{1,2^{*}}$, Nathaniel J Barber ${ }^{2}$, Grzegorz T Kowalik², Jennifer A Steeden², John Porter ${ }^{1}$, \\ John Malcolm Walker ${ }^{1}$, Vivek Muthurangu ${ }^{2}$
}

From 19th Annual SCMR Scientific Sessions

Los Angeles, CA, USA. 27-30 January 2016

\section{Background}

Exercise intolerance is a common feature of many noncardiac and non-respiratory diseases. The causes are often multifactorial and include secondary cardiac-respiratory dysfunction, as well as skeletal muscle abnormalities. Unfortunately, it is difficult to determine the exact cause using conventional cardiopulmonary exercise testing (CPET). Therefore, we have developed MR augmented CPET that allows simultaneous evaluation of cardiac output and tissue oxygen extraction in addition to conventional CPET measures. To demonstrate the utility of this technique we performed MR-CPET on patients with sickle cell disease (SCD). The aim of this study was to demonstrate that MR-CPET could be used to define the physiological factors associated with their poorly understood exercise intolerance.

\section{Methods}

14 patients with homozygous sickle cell disease (age: $30-$ 41) and 14 healthy volunteers (age: 25-37) underwent MR-CPET. Exercise was performed on MR-compatible ergometer (Lode, Groningen, The Netherlands) and minute ventilation $(\mathrm{VE})$, oxygen consumption $\left(\mathrm{VO}_{2}\right)$, and carbon dioxide production $\left(\mathrm{VCO}_{2}\right)$ were assessed using a commercial respiratory gas analyser (Ultima, MedGraphics, St. Paul, USA) with modified sampling tube that was MR compatible. Aortic flow was simultaneously continuously measured using a previously validated real-time UNFOLD-SENSE spiral PCMR sequence. MR data was used to derive cardiac output $(\mathrm{CO})$, heart rate $(\mathrm{HR})$ and stroke volume (SV) curves

\footnotetext{
${ }^{1}$ The Hatter Cardiovascular Institute, University College London, London, UK
} Full list of author information is available at the end of the article during exercise. Arteriovenous oxygen content gradient $\left(\mathrm{AVO}_{2}\right)$ curves (a measure of tissue oxygen extraction) were calculated by dividing the $\mathrm{VO}_{2}$ and $\mathrm{CO}$ curves.

\section{Results}

All participants completed exercise with no adverse outcome including the sickle group. MR-CPET measures at rest and exercise are shown in table 1 . The main finding was that peak $\mathrm{VO}_{2}$ was significantly lower in patients (fig. 1a). This was partly driven by a reduced $\mathrm{CO}$ response (fig. 1b) in SCD patients, due to a lower peak heart rate. However, linear regression analysis demonstrated that reduced $\mathrm{AVO}_{2}$ response (fig. 1c) was the main driver of reduced peak VO2 (p-0.018) in patients.

\section{Conclusions}

Using MR-CPET we have been able to show for the first time that exercise intolerance in SCD is due to reduced skeletal muscle oxygen extraction. This may be due to vascular network rarefaction, muscle fibrosis, or reduced mitochondrial function; all of which have been demonstrated in histology specimens in SCD. Without simultaneous CO measures it is would not have been possible to demonstrate the importance of reduced tissue extraction. This demonstrates the power of MR-CPET and we believe this technique could aid in better understanding of exercise intolerance and possibly better therapeutic interventions.

\footnotetext{
Authors' details

${ }^{1}$ The Hatter Cardiovascular Institute "University College London, London, UK. ${ }^{2}$ Great Ormond Street Hospital for Children, Institute of Cardiovascular
} Science, London, UK.

Published: 27 January 2016 
Table 1 Resting and peak values during MR-CPET

\begin{tabular}{|c|c|c|c|}
\hline Variable & Normal Mean (range) & Disease Mean (range) & P-value \\
\hline Resting $\mathrm{VO} 2, \mathrm{Lmin}^{-1}$ & $0.210(0.17-0.25)$ & $0.231(0.19-0.27)$ & 0.38 \\
\hline Peak VO2, $\mathrm{Lmin}^{-1}$ & $1.1(0.9-1.3)$ & $0.7(0.56-0.76)$ & $0<0.001^{* *}$ \\
\hline Resting cardiac output, $\mathrm{Lmin}^{-1}$ & $6.7(5.9-7.5)$ & $8.1(7.1-9.2)$ & $<0.05^{*}$ \\
\hline Peak cardiac output, $\operatorname{Lmin}^{-1}$ & $13(12-14)$ & $12(11-13)$ & $<0.05^{*}$ \\
\hline Resting stroke volume, mlbeat $^{-1}$ & $98(84-111)$ & $109(98-119)$ & 0.17 \\
\hline Peak Stroke volume, mlbeat $^{-1}$ & $101(81-120)$ & $116(105-27)$ & 0.16 \\
\hline Resting heart rate, bpm & $66(56-77)$ & $77(72-81)$ & 0.067 \\
\hline Max heart rate, bpm & $138(124-152)$ & $120(111-129)$ & $<0.05^{*}$ \\
\hline Resting tissue extraction, $\mathrm{m} / \mathrm{O} 2 \mathrm{ml}-1 \mathrm{blood}$ & $0.31(0.26-0.35)$ & $0.28(0.24-0.32)$ & 0.34 \\
\hline Peak tissue extraction, $\mathrm{m} / \mathrm{O} 2 \mathrm{ml}-1$ blood & $0.90(0.79-1.02)$ & $0.51(0.43-0.59)$ & $<0.001^{* *}$ \\
\hline
\end{tabular}
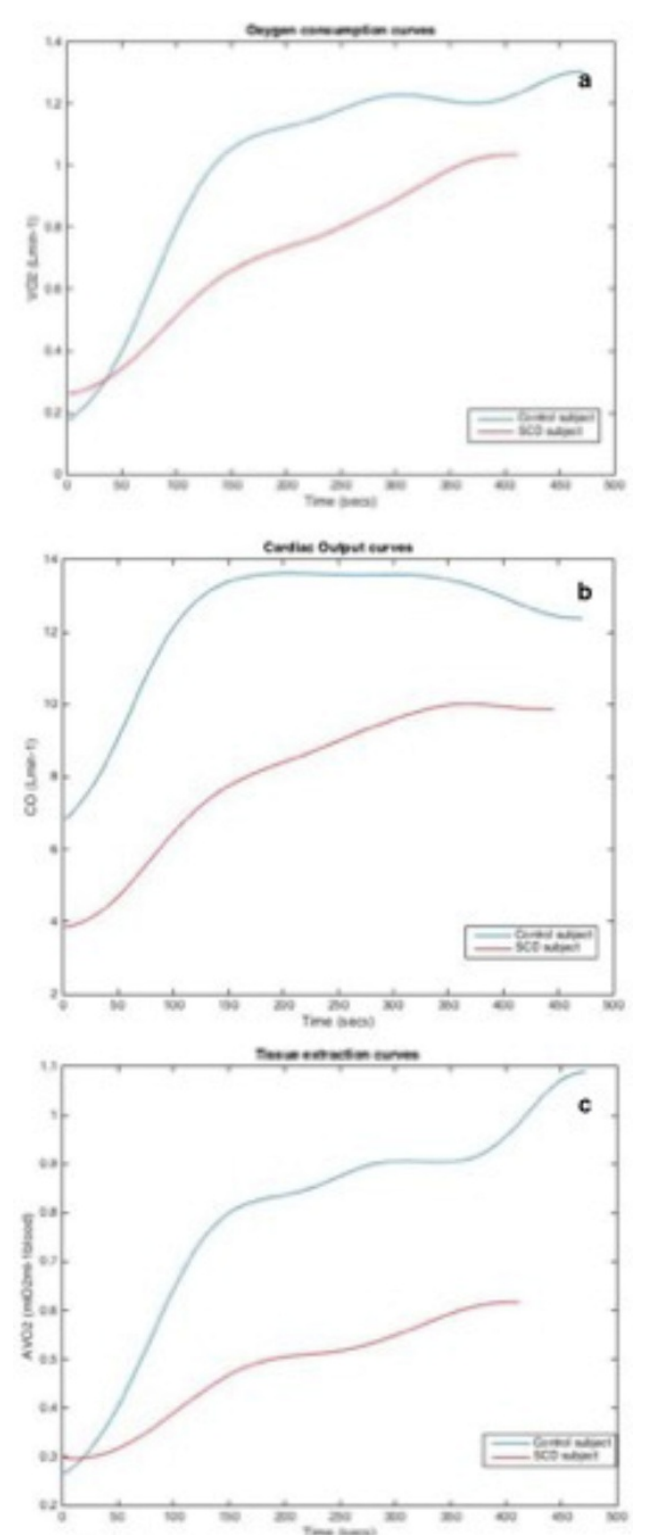

Figure 1 (a) Oxygen consumption (b) Cardiac Output and (c) Tissue extraction during exercise.

Submit your next manuscript to BioMed Central and take full advantage of:

- Convenient online submission

- Thorough peer review

- No space constraints or color figure charges

- Immediate publication on acceptance

- Inclusion in PubMed, CAS, Scopus and Google Scholar

- Research which is freely available for redistribution 